\section{SAAAA JOURNAL}

\title{
Relation of Dance and Music to Balinese Hinduism
}

\author{
I Gede Arya Sugiartha \\ Rector \\ Indonesian Institute of Art Denpasar \\ Denpasar, Indonesia \\ de.arya.66@gmail.com
}

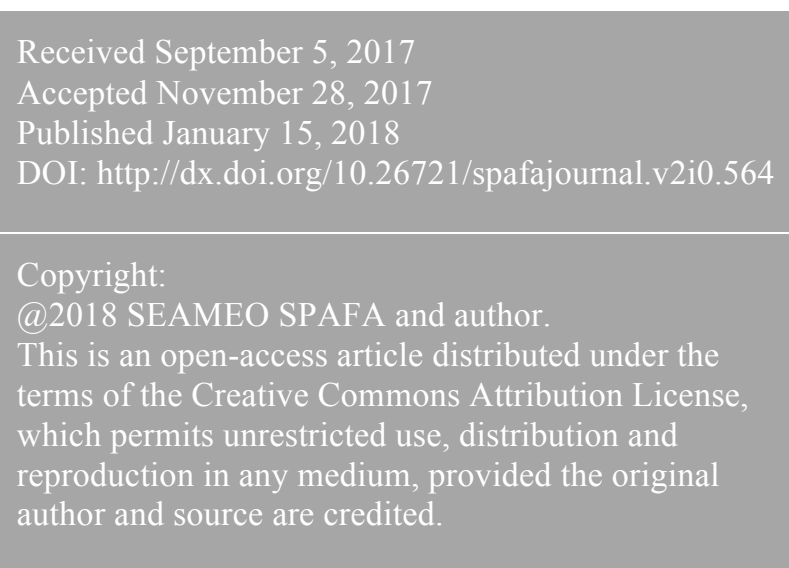

\begin{abstract}
Balinese traditional dance and music are imbued with the values, cultural identity and artistic expression of the Balinese, with close links to the Hindu religion. Balinese Hindus in particular strongly believe that dance and music are mediums to bring them closer to the gods. In Bali, religion, art and culture are fused together in daily life. For the Balinese, no religious ceremony is complete without the presence of art and culture. Equally as important as dance and music, living in harmony with the environment for the sake of human survival is another strong conviction among the people of Bali. In addition to music and dance performances, nature is believed to hold many supernatural powers which cannot be understood by mankind. People are expected to maintain a harmonious relationship between all elements. This is why dance and music are continuously maintained and developed over time. The strong adherence of the Balinese people to Hinduism contributes to the preservation of traditional dance and music so that these traditions may never be lost. This paper was first presented on the Workshop of Hindu Art in Southeast Asia hosted by SEAMEO SPAFA, on May 28, 2017, at ISI Denpasar and has been peer-reviewed.
\end{abstract}

Keywords: dance; music; Hinduism; Bali 


\section{Introduction}

Bali is a small island in the Indonesian archipelago. Its total size is about 5,632.86 square kilometres. Despite its small size compared to the other islands of the archipelago, Bali is internationally renowned as a tourist destination. One of the various reasons for which Bali has become famous is its unique culture that has developed through creativity and which has been transmitted from generation to generation. The inhabitants of the island, known as "manusia Bali", share characteristics with other peoples of Indonesia. Despite these similarities, philosophically speaking, there are two unique characteristics among the Balinese that set them apart from the other groups. First, while the majority of Indonesians are Muslim, most of the Balinese are Hindu. Second, the Balinese are highly skilled in the field of the arts, to the extent that the people of Bali as a whole are considered as artists. The Hindu religion among the Balinese is a sturdy force in the preservation of nearly all Balinese art forms. Bali is therefore renowned for its many art forms, such as the performing arts, visual arts, architectural arts, and literature.

Hinduism is the oldest living religion in Indonesia. Based on historical evidence, the Hindu religion originated from India and flourished exponentially in Indonesia in the early $4^{\text {th }}$ century. Some of the Hindu kingdoms that once ruled in Indonesia are the Kutai in East Kalimantan, Tarumanegara in West Java, the kingdom of the Warmadewa Dynasty with its famous king named Udayana in Bali, and the Majapahit Kingdom in East Java. After the fall of Majapahit in the $14^{\text {th }}$ century CE and the reign of the Islamic kingdoms in various parts of Indonesia, the Hindu kingdoms only survived in Bali. Therefore, Bali is often known as the place of Hinduism in Indonesia. Hinduism is one of the official religions recognized by the Indonesian government despite its minority. Hinduism in Bali has been adjusted to the original culture of the Balinese people, so that the ordinance of the ritual execution has its own uniqueness. The implementation of the teachings of Hinduism that are packed with Balinese culture are mutually supportive and also reinforcing, thereby allowing Hinduism to grow, develop and stay current to present day.

The Hindu religion teaches that there are three ways to execute the instructions of God: tatwa (philosophy), susila (ethics) and upacara (ritual/ceremony). The first, tatwa, is a life philosophy according to which the following need to be carried out evenly: satyam (truth), siwam (goodness), and sundaram (beauty). By virtue of this understanding, world perfection can be achieved if humankind upholds the values held in truth, logic and intuition; then, by constantly enacting good deeds upon others and the environment in all actions, humankind is able to do something in a beautiful way. Secondly, susila suggests that in life, mankind should have ethics and demonstrate good behaviour. Humankind is not about living alone in the world; it requires interaction and understanding to create a tolerant, peaceful, and harmonious society. Thirdly, upacara is an expression of gratitude and respect towards God by way of performing yadnya, which is a heartfelt presentation of a ceremony or ritual.

Tri Rnam, which is divided to three components, namely God (Dewa Rnam), ancestors (pitra rnam), and saints (rsi rnam), is the reason that Hindu peoples carry out yadnya according to their capabilities and conditions. The debt to God is because 
God is the creator of the universe that gives life to all mankind, the debt to ancestors is because our ancestors cause us to exist and guide us in life, while the debt to the saints is that it is because of them that we learn science.

Yadnya can be performed through various means, starting from a prayer recital with an offering $\left(\right.$ banten $\left.^{l}\right)$, working selflessly $\left(n g a y a h^{2}\right)$, building a temple, and performing artistic activities. The execution of this yadnya or ritual can yield various kinds of activities and cultural products, such as dance and music. The use of art or beauty as a medium of yadnya is revealed in Hindu holy books/scriptures, one of which is Natya Sastra. The book of Natya Sastra was written by the philosopher Bharata in the $2^{\text {nd }}$ century CE and is known as the source of Hindu aesthetics. In the book, it is explained that art is an offering or yadnya: art is not solely to please the human senses, but is a tool to spiritualization in one's life. Art in Hindu's perspective has the function of cleansing, purifying the emotions and glorifying it.

This paper will examine the relation between art - especially dance and music, with Balinese Hinduism which is widely observed in the execution of yadnya or ritual. Based on these topics, the author uses dance ethnology and ethnomusicology, which is to study dance and music as a culture. One focus of the study of dance and music as a culture is the search for meaning through searching of functions and their use in various human activities. The relationship between Balinese music and dance with Hinduism in Bali is more on the relation between function and usage; therefore, the function theory will be used as the analytical blade in this paper. Soedarsono (1985: 18), an expert in history of Indonesian performing arts, said that there are three primary functions of Indonesian performing arts, namely: as a medium of ceremony / ritual, as personal entertainment, and as aesthetic show / presentation. Furthermore, based on the results of Seni Sakral dan Profan Seminars in 1972 in Bali, there are three functions of Balinese dance, namely: as a wali, bebali, and balih-balihan. Wali and bebali are both related to ritual function, while balih-balihan is related to Balinese dance function as the art of show or aesthetic presentation. In searching Balinese dance and music ritual functions, the meaning of why Balinese uses dance and music in various executions of yadnya in Hindu religion will be revealed.

\section{Ritual Function of Balinese Dance and Music}

The functions of Balinese traditional dance and music are mostly subject to the execution of Hindu religious activities. In the mythology of Siwa Nataraja, it is mentioned that Dewa Siwa is a supreme god as the creator of dance. When the Lord Siwa organized the universe, he did it through dancing. Therefore, there is the realization of world order and the harmony achieved therein that are related to dance (Tim 2010: 5). As for music, as mentioned in the Prakempa inscription (Bandem 1988 31-33), sound and voice originate from fruitive penances (yoga) of the trilogy of

\footnotetext{
${ }^{1}$ Banten is a form of offering for the God on a combination of flowers, leaves, fruits, and meats those are arranged artistically with full of symbols and meanings.

${ }^{2}$ Ngayah is a form of spiritual devotion within various activities such as dancing, playing gamelan, cleaning the temple, and many others which are categorized as selfless activities as a form of homage to God.
} 
gods, Sanghyang Tri Wisesa ${ }^{3}$ (Brahma, Wisnu, Siwa), and were then arranged by the sage Wiswakarma so as to become ten beautiful sounds. These ten sounds were then packaged into five pelog tone scales and five selendro tone ${ }^{4}$ scales. These mythologies have been adopted as a principle conviction among the Balinese, insofar as dance and music are not merely entertainment, but are also functions to maintain the balance of life, both materially and spiritually, real and unreal, inwardly and outwardly.

In Bali, Hindu religion, art and culture are intertwined in daily life, with performing and visual arts considered as integral parts of religious ceremonies. Customarily, traditional performing arts are presented in the Balinese Hindu temple ceremony known as piodalan. Dances such as Rejang, Baris Gede, Sanghyang, and Topeng Sidakarya, and musical performances such as the Gamelan of Gong Gede, Selonding, and Gong Beri are some of the various performances associated with Hindu religious rituals in the temple. Through the performance of dance and music, the Balinese express their sense of heartfelt devotion towards God. They dance, play music, chant devotional songs, pray, and work together on the occasion of a temple festival. Therefore, piodalan is not only a religious festivity but also a social occasion and theatrical event (Dibia 1985: 1).

In addition to piodalan (temple festival), Balinese traditional dance and music are also used in other Hindu religious activities such as ruwatan (sacrifice), bayar kaul (pay vows), and bersih desa (purification). The ruwatan ceremony is aimed at lifting bad luck from a child who was born on certain days that are considered unlucky or bad days according to Balinese Hindus. One example is when a child is born on tumpek wayang (Sabtu kliwon wuku wayang). In the Sapuhleger ${ }^{5}$ mythology, it is mentioned that a child born on tumpek wayang is destined to become a meal of the Lord Kala (Bagus, in Soedarsono et al. 1985: 57). The philosophical significance of this story is the worry that the child would experience dangerous incidents in his/her life. Therefore, to protect the child from bad luck, the child needs to be given a ruwatan ceremony by way of a Sapuhleger shadow puppet performance. Sapuhleger shadow puppetry performed during the ruwatan ritual uses stories related to the murwakala, or the birth of Lord Kala. After the Sapuhleger shadow puppet performance, the children for whom the ritual is performed are then consecrated by the puppeteer, and in so doing they are deemed to have been freed from the threat of Lord Kala (Fig. 1).

\footnotetext{
${ }^{3}$ Sang Hyang Tri Wisesa or often called Tri Murti is the three manifestations of God as a creator (Brahma), protector (Wisnu), and destroyer (Siwa).

${ }^{4}$ Within musical system, Balinese music is commonly known that there are two tuning systems, namely pelog tone scale and selendro tone scale which are quite different than the Western (diatonic) music tuning system. On a pelog tone scale the gap between one tone to another is quite different, while the selendro tone scale moves on the opposite way from the pelog tone scale. The pelog tone scale posseses a strong characteristics or masculinity, while the selendro tone scale is a lot more feminine.

${ }^{5}$ Sapuhleger is mythological tale about the pursuit of Rare Kumara who will be made a meal by Betara Kala because of his birth on Sabtu Kliwon Wuku Wayang or often known as Tumpek Wayang. The end of this tale says that Rare Kumara was saved by a puppeteer who was playing a puppet show.
} 


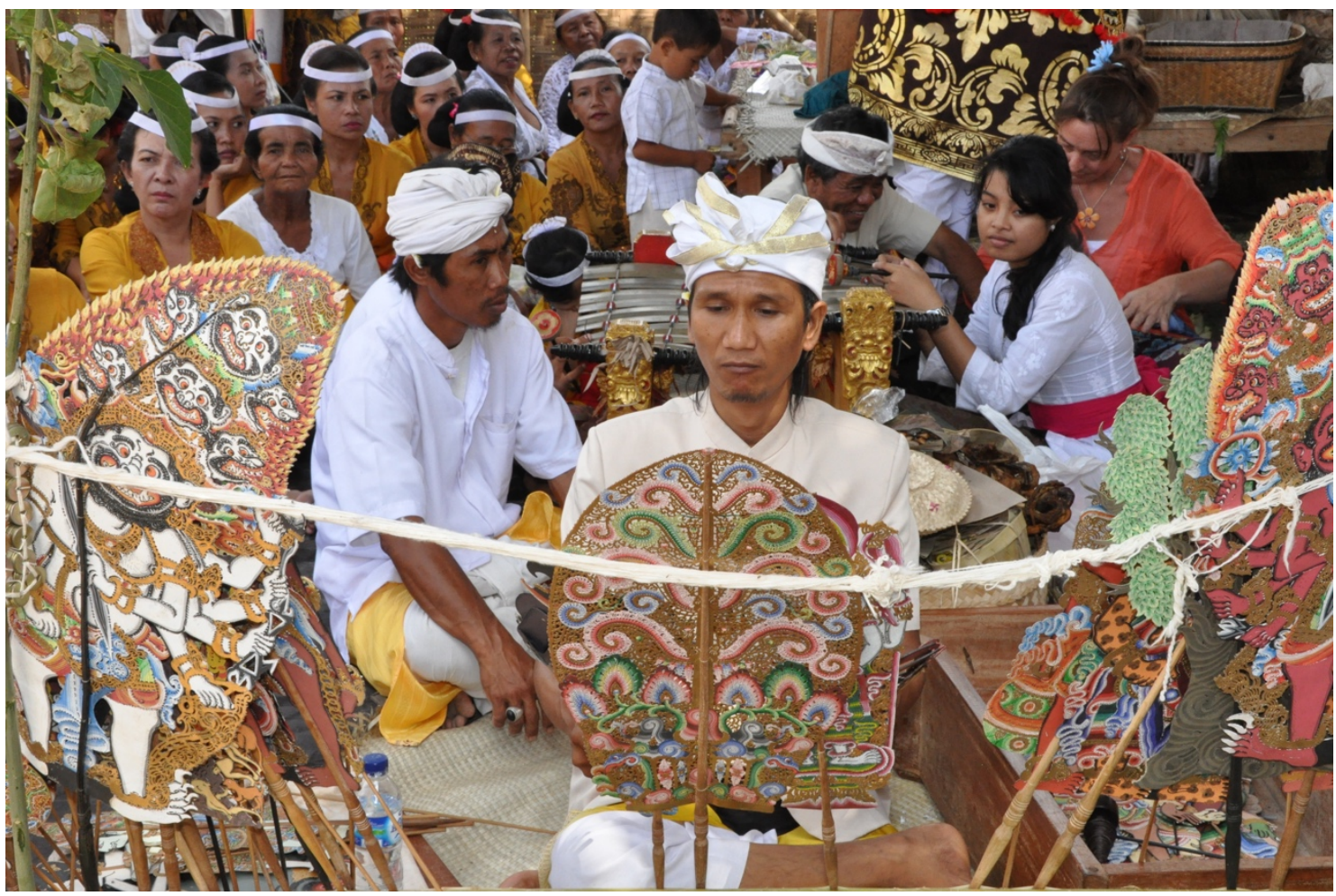

Fig. 1 Sapuhleger Puppet. Source: Archive Center of ISI Denpasar

Similar to the Wayang Sapuhleger performance, the bayar kaul or mayah sesangi (making vows) ceremony is an effort to break oneself free from one's "vow" which had been made in a prayer beforehand. For instance, the people of Pujungan, Pupuan and Tabanan have maintained the masesangi tradition to this day. For example, if one is suffering from an illness or disease, one can make a vow to perform a sacred Barong and Rangda performance to be carried out once recovered. Whenever vows made are due to be fulfilled, one would carry out a ritual to honour these vows by performing a sacred Barong dance (interview with I Wayan Sedana, Bendesa Adat/head of traditional village authority of Pujungan village, January 25, 2017).

The ceremony of bersih desa is a ritual to invoke blessings for villagers and the environment to protect them from disease and natural disasters. Balinese Hindus believe that certain days, such as sasih keenem ${ }^{6}$ (the sixth month in the Balinese lunar calendar), are vulnerable times to contract illnesses. During this period, it is believed that many people fall ill and natural disasters occur. To relieve the people and their environment from such dangerous threats, one of the rituals performed for the bersih desa is what is known as "nangluk merana" through the music and dance of Sanghyang Dedari, Sanghyang Jaran, and Barong Ngelawang. In conducting these

\footnotetext{
${ }^{6}$ Sasih means month, traditional Balinese people also recognize there are twelve months in a year according to Balinese calendar namely sasih kasa, sasih karo, sasih ketiga, sasih kapat, sasih kelima, sasih keenam, sasih kepitu, sasih keulu, sasih kesanga, sasih kedasa, sasih sada, and saih jesta. One last for 30 days but the fall of every sasih is quite different, let say the fall of sasih kesanga is not similar with the month of September, but similar with the fall of March on common calendar.
} 
ritual performances, the people are no longer plagued by the worry of potential threats and disasters, so that they may live peacefully.

\section{Balinese Traditional Dance}

Depending on its social function in Balinese culture, Balinese dance is, as mentioned earlier, categorized into wali, bebali, and balih-balihan dances. Wali dance is a sacred performance for ceremonies/ritual activities, and is instrumental to the ceremony's success. One example is the Rejang Dewa dance; it is performed by dozens of female dancers who dress in white and yellow, dancing softly and gracefully (Fig. 2). They dance while circling the temple court yard, to welcome the presence of the gods cheerfully. In performing the Rejang Dewa dance, people believe that the gods will be pleased and entertained, therefore bestowing their blessings onto the people. In addition to the Rejang Dewa dance, there is another wali dance called Baris Gede. This dance depicts a number of guards who are prepared to secure the situation at the time when the gods make their descent to earth. As the dance depicts a number of guards, Baris Gede dancers are adorned with a spear (tombak), a shield (tamiang) and a dagger (keris). The Baris Gede dance is presented in the temple court yard, with the musical accompaniment of the Gong Gede gamelan (Fig. 3). Another wali dance that is presented to ensure the successful completion of a ceremony is Topeng Sida Karya. The term sida karya itself means 'complete and successful'. As a result, the performance of this masked dance is mandatory at every ritual in order to achieve spiritual success and completion. The Topeng Sida Karya dance is performed by a dancer who wears a frightening white mask with large and crooked teeth, and loose white hair (Fig. 4). When the dancer performs the Sida Karya dance, he carries out his duty like a sage, dancing using highly expressive gestures and movements, accompanied by sacred chants (Bandem and de Boer 2014: 69).

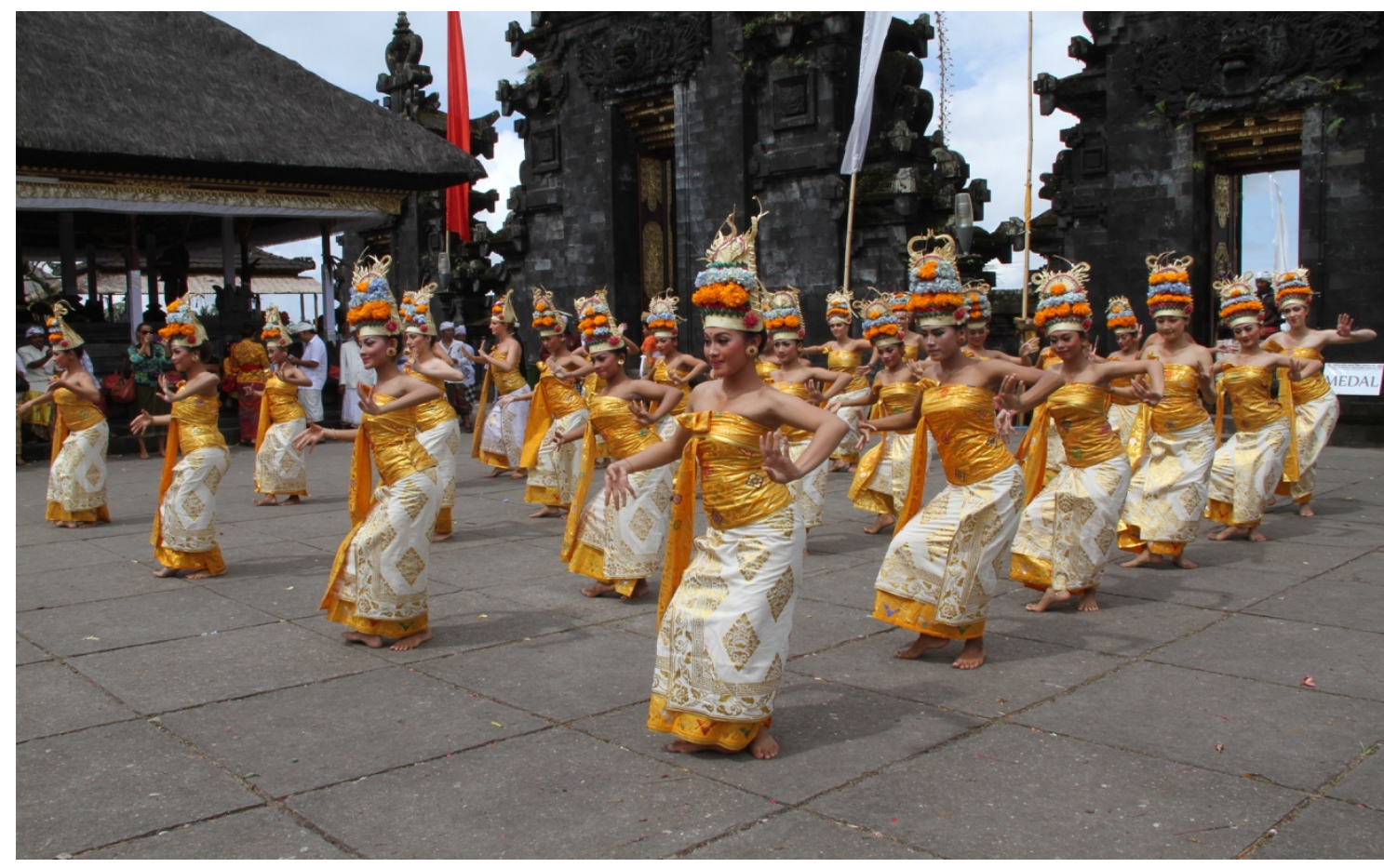

Fig. 2 Rejang Dewa Dance. Source: Archive Center of ISI Denpasar 


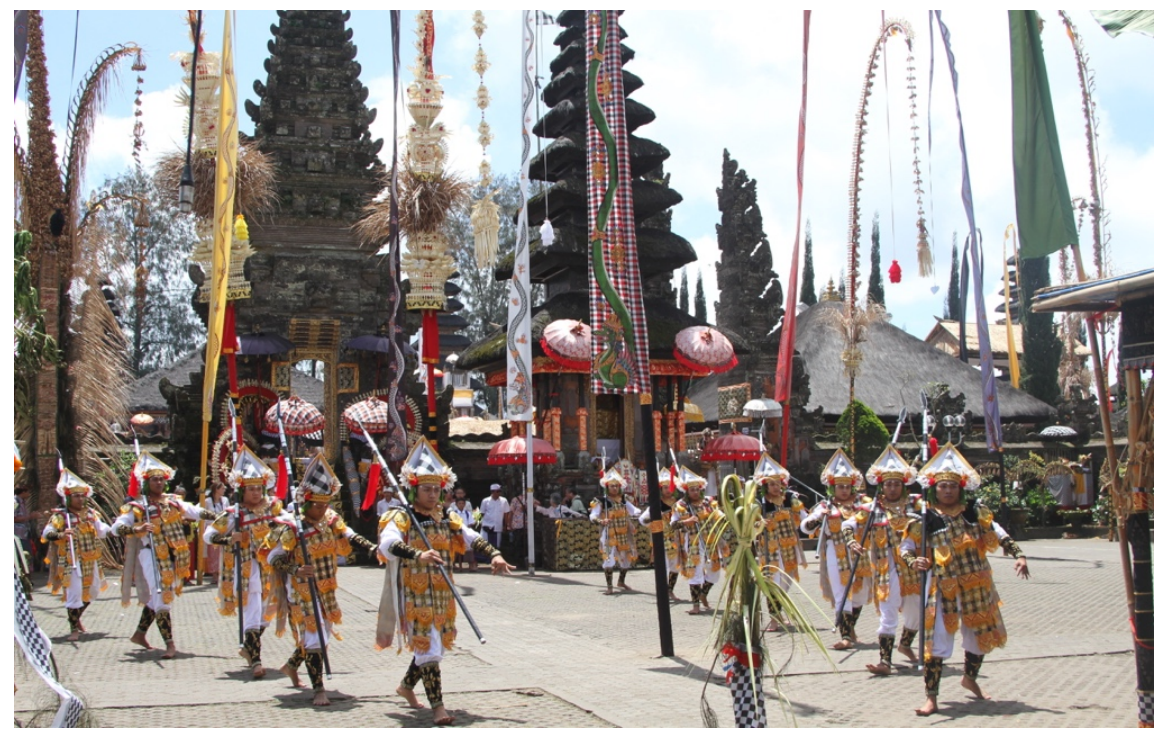

Fig. 3 Baris Gede Dance. Source: Archive Center of ISI Denpasar

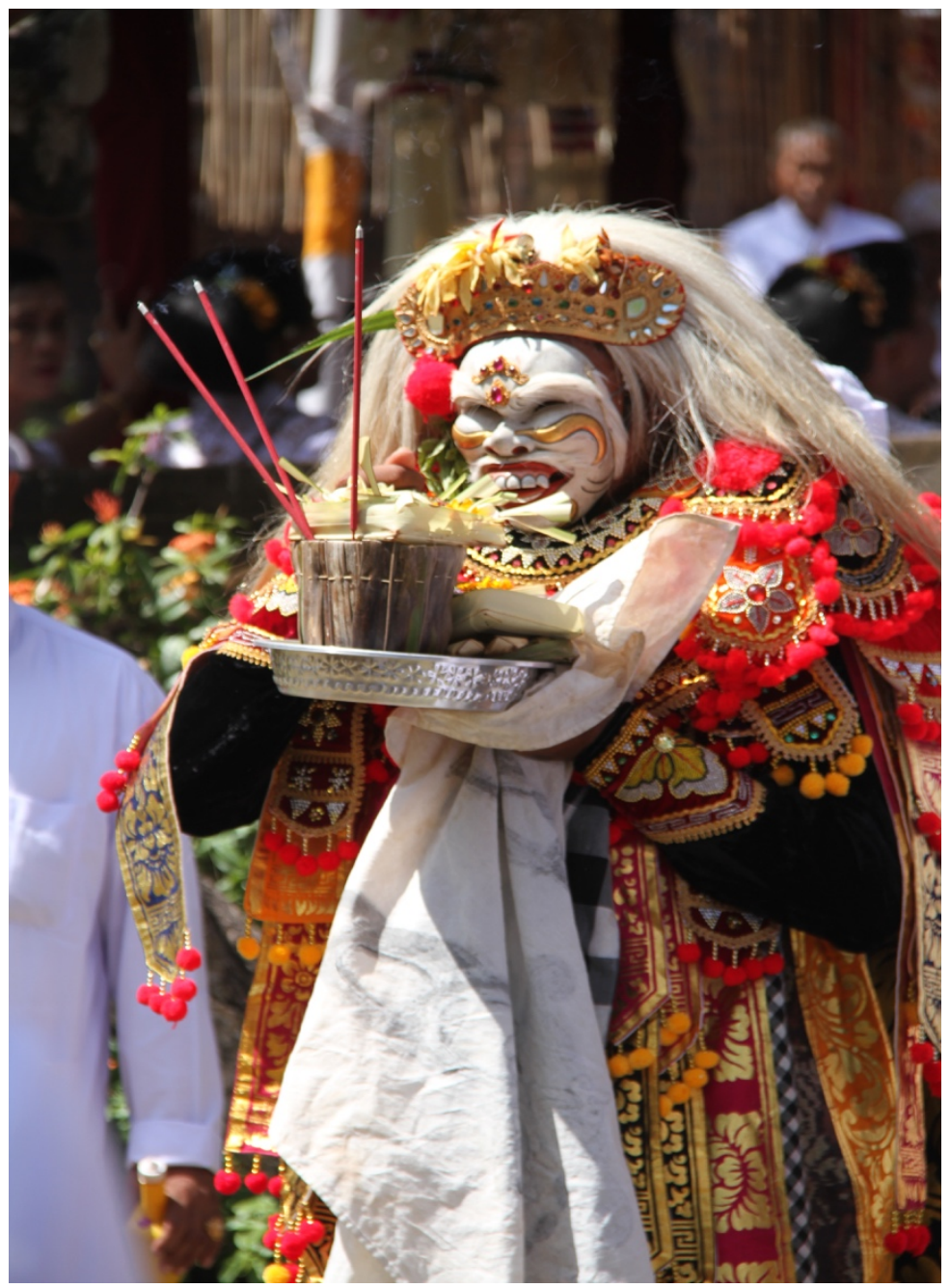

Fig. 4 Topeng Sidakarya. Source: Archive Center of ISI Denpasar 
The wali dance that is performed for the bersih desa ceremony is called Sanghyang Dedari. It is presented by two young girls who have not yet experienced menstruation. The Sanghyang Dedari dance is performed to invoke blessings so that the people can be bestowed the protection of god (Fig. 5). It is accompanied by songs and billowing incense smoke. Two Sanghyang dancers are in a state of trance and considered to be channelling the spirits of heavenly nymphs, then dancing gracefully to the vocal music of kecak. Another wali dance is the Sanghyang Jaran, performed by a male dancer who is also in a state of trance and considered to embody the spirit of the horse. This is why the dance movements resemble an agile horse dancing in a hot blazing fire without ever feeling the heat of the fire.

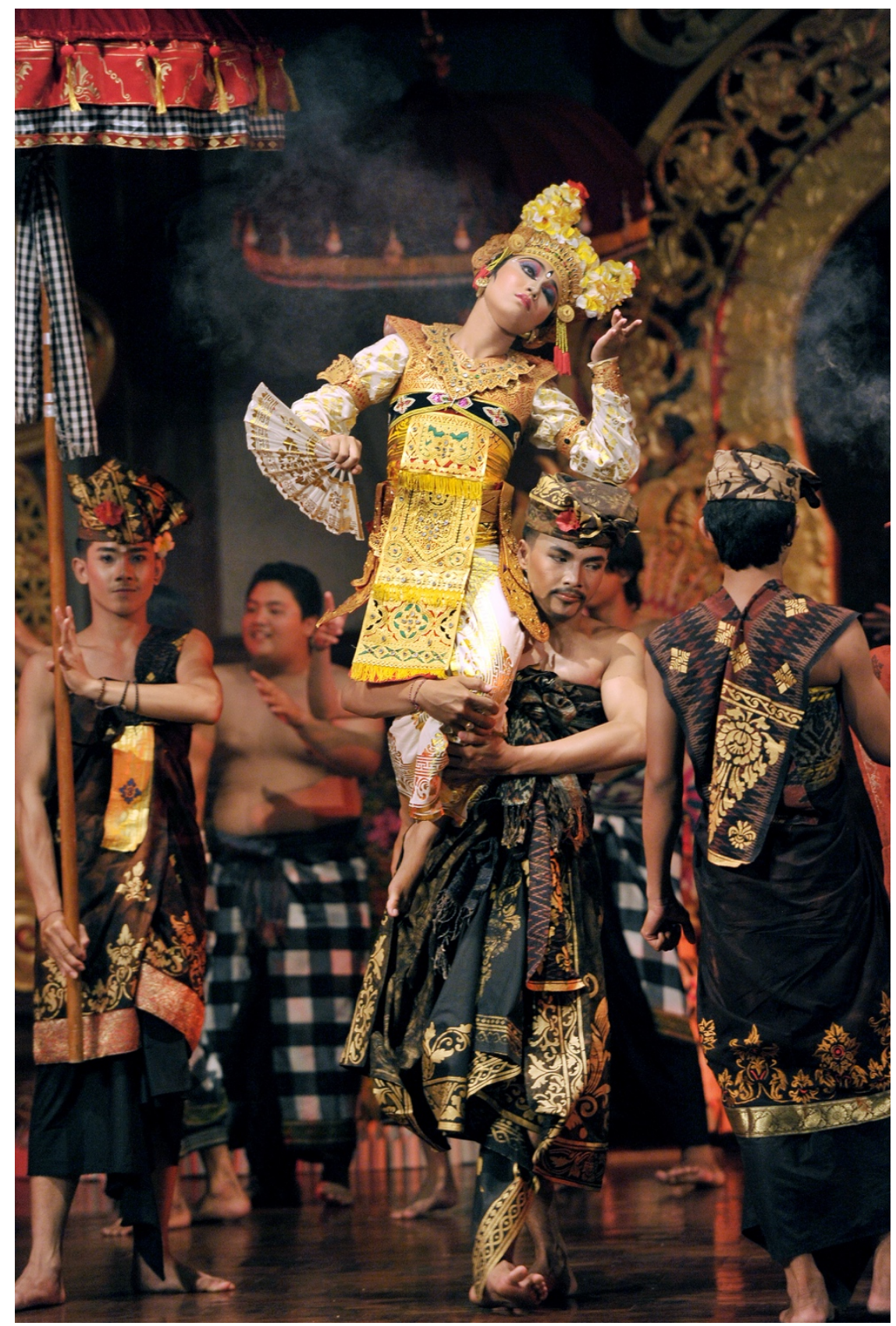

Fig. 5 Sanghyang Dedari. Source: Archive Center of ISI Denpasar 


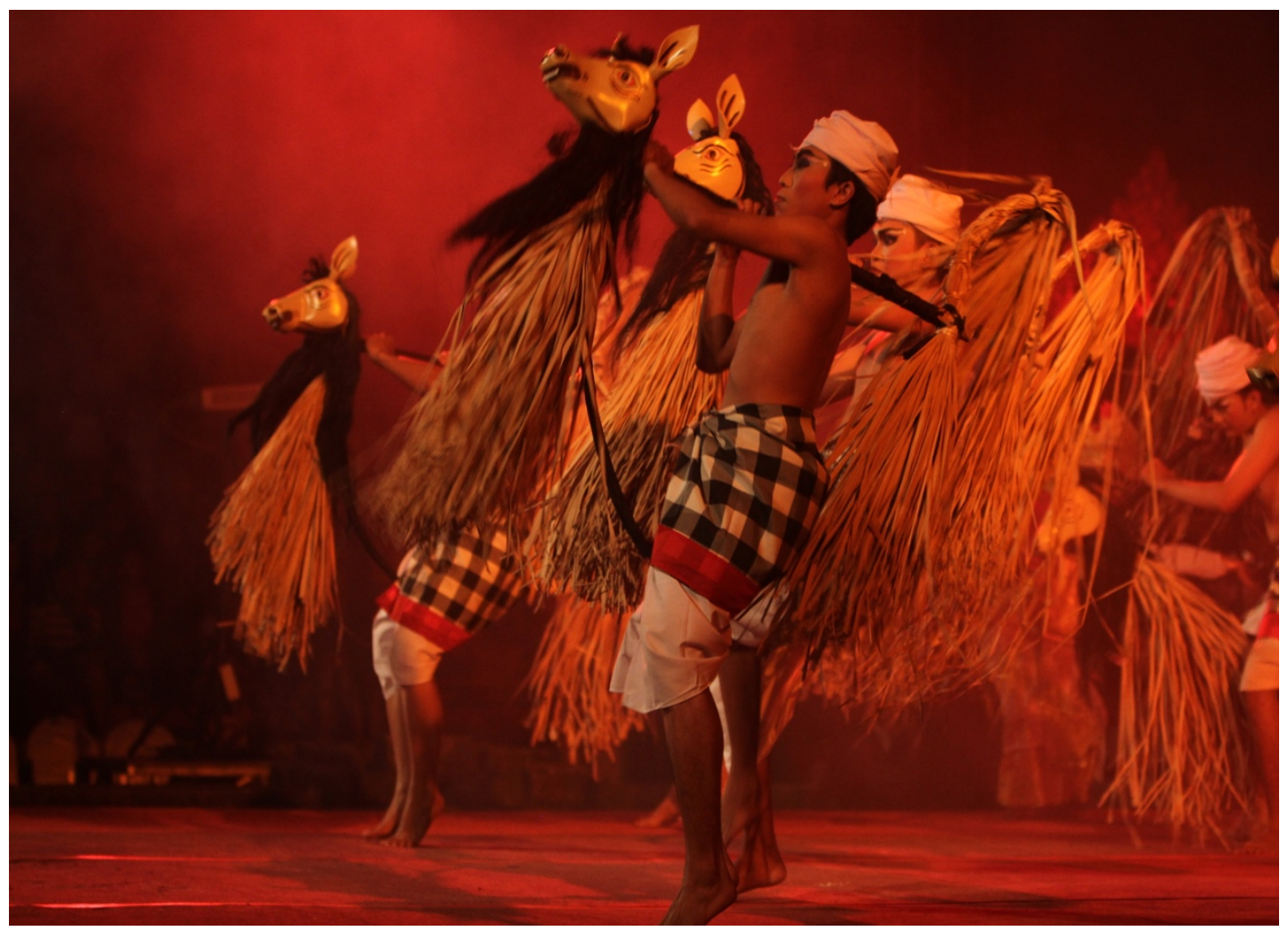

Fig. 6 Sanghyang Jaran. Source: Archive Center of ISI Denpasar

Bebali dances are performed for ceremonies/ritual activities; however, they tend to support, as opposed to determining, the successful completion of the ceremony. Some examples of bebali dances are Gambuh, Wayang Wong, Telek and Barong. Gambuh is a dialogic dance drama which uses the story of Panji (known as Inao in Mainland Southeast Asia), which is believed to be the oldest dance drama in Bali. Gambuh dance drama may be performed in a series of temple ceremonies and other ritual activities, but its nature does not determine the success of the ceremony (Fig. 7). Wayang Wong dance drama uses the story of the Ramayana in order to support the implementation of the ceremony. In addition, Telek, Barong and Rangda are performed as a unity of dances, also to support the execution of the ceremony. In some other regions, like in Tabanan, Telek, Barong and Rangda function as wali dances, thus being essential to the successful completion of the ceremony. 


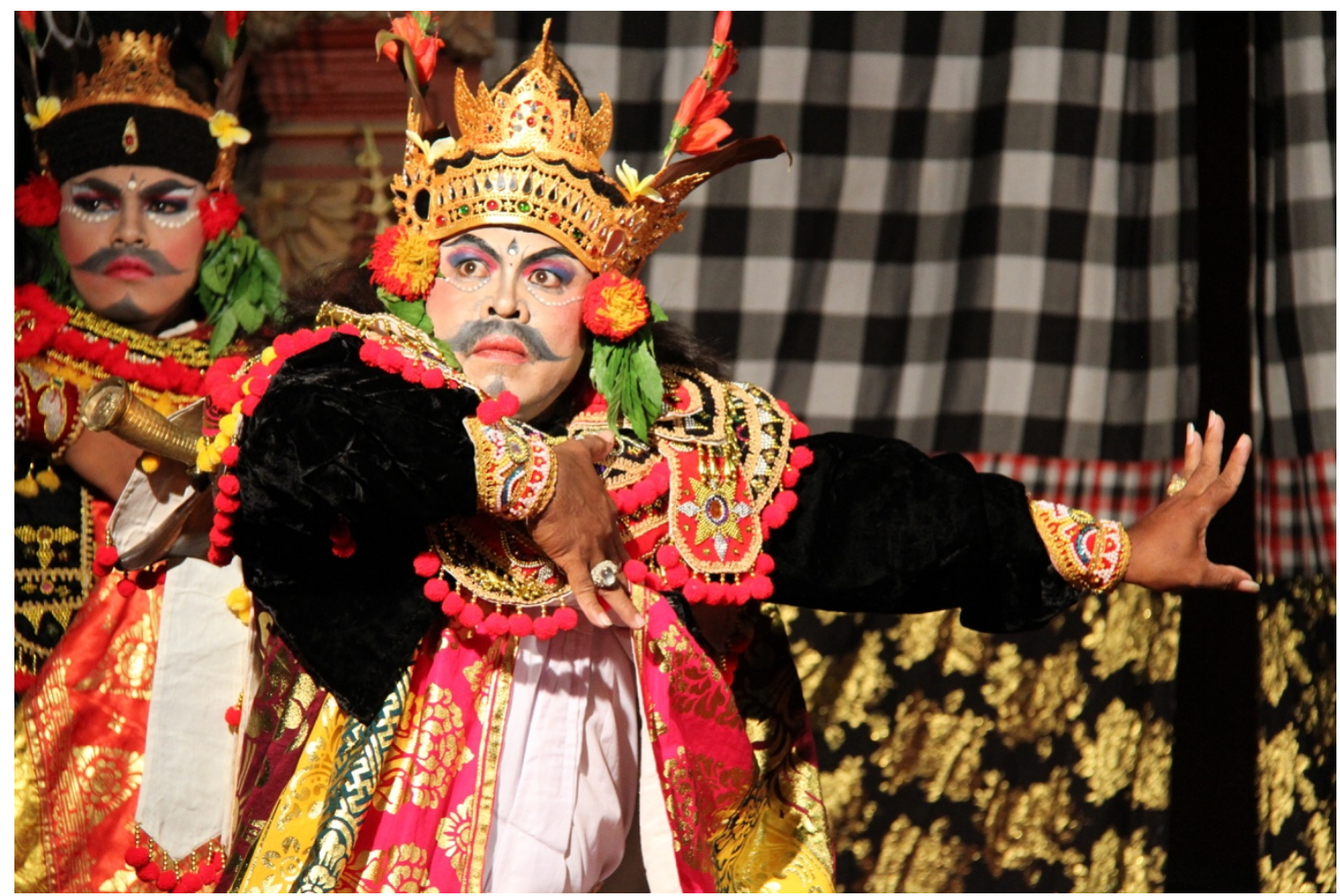

Fig. 7 Gambuh Dance. Source: Archive Center of ISI Denpasar

Meanwhile, balih-balihan dances are performed for entertainment purposes in ritual ceremonies or other activities. Balih-balihan dances have an emphasis on aesthetic presentation with the aim of pleasing the audience. Some examples of balih-balihan dances are Legong Keraton, Joged Bumbung and Kebyar. The Legong Keraton used to be a royal palace artistic performance staged to welcome royal guests. Now that the king no longer wields political power, Legong Keraton is staged for anyone's entertainment and anywhere as needed. As for the Joged Bumbung dance, it is a social dance performed in pairs between joged dancers (female) and pengibing ${ }^{7}$ (males) designated from among the audience. This dance is performed purely for entertainment within the community. As for the Kebyar dance, it is a new genre that was born in the early $20^{\text {th }}$ century. Also an entertainment dance, it is often performed to enliven a temple ceremony and for hotels and restaurants. Today, the Kebyar dance is the most popular, not only in Bali, but also throughout Indonesia and overseas (Figs. 8 and 9).

\footnotetext{
${ }^{7}$ Pengibing is a male dancer who dances with the female dancer in joged performance. Pengibing is chosen from the audience watching the joged performance who is spontaneously invited to dance together by the joged dancer.
} 


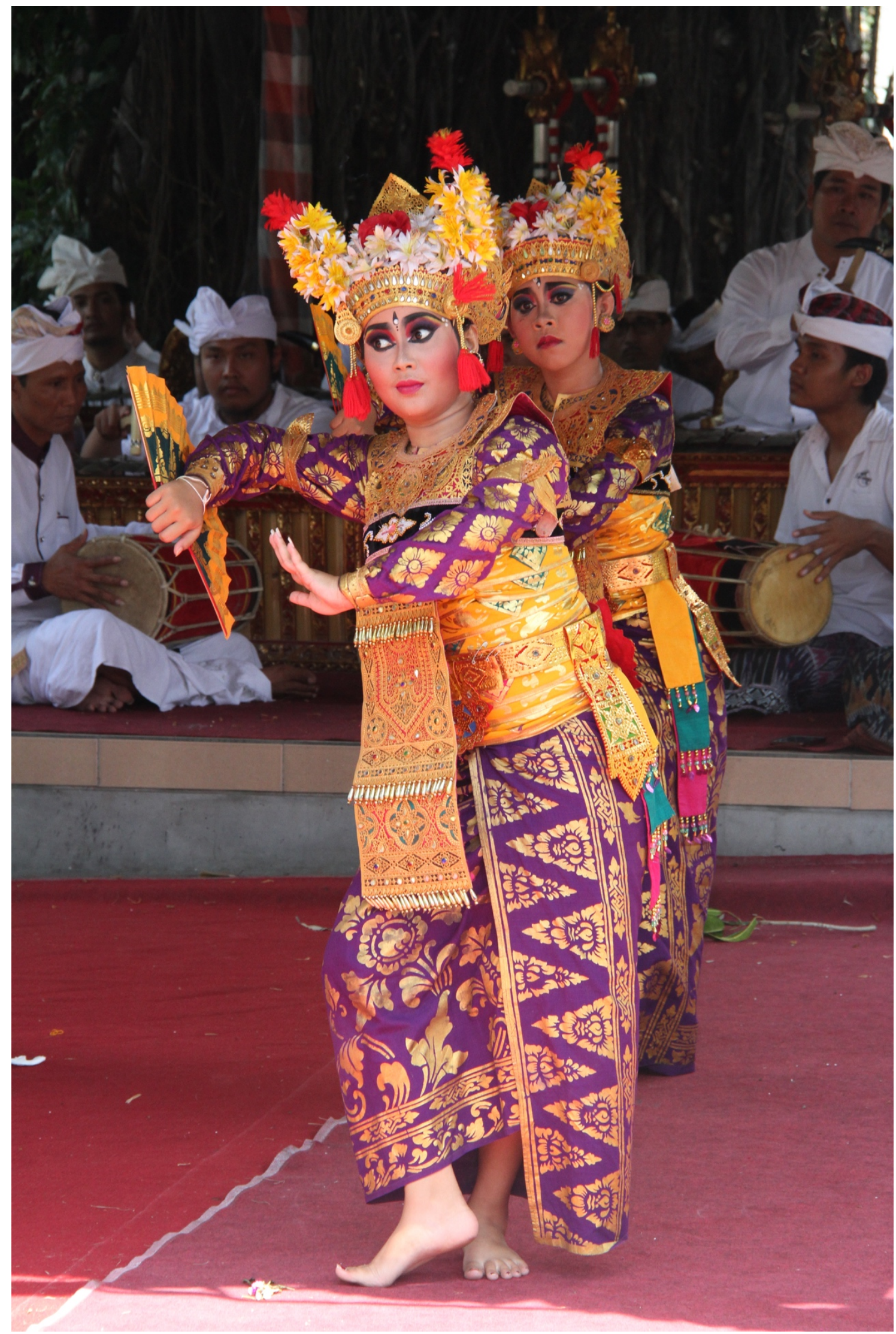

Fig. 8 Legong Dance. Source: Archive Center of ISI Denpasar 


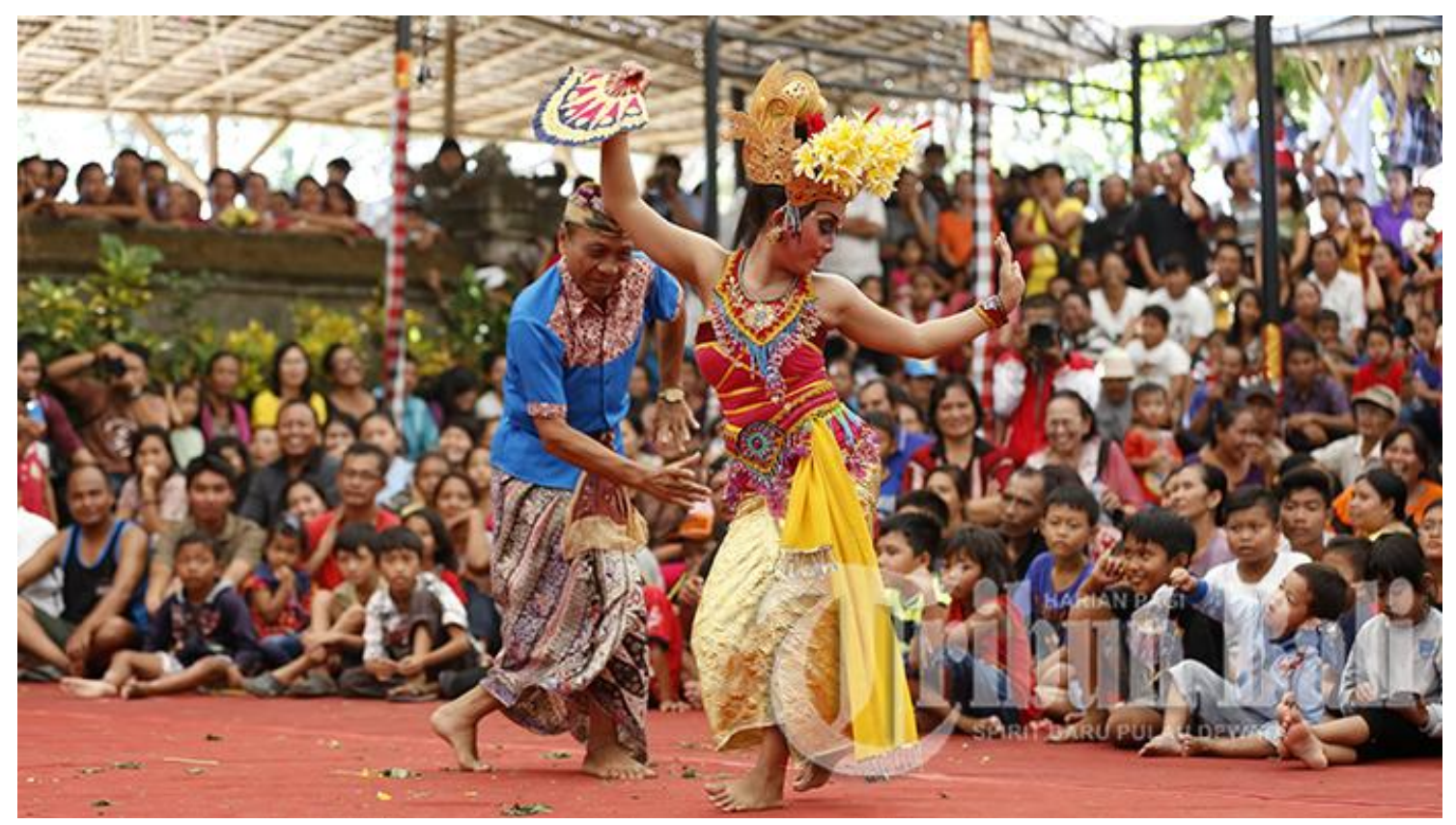

Fig. 9 Joged Bumbung Dance. Source: Archive Center of ISI Denpasar

Balinese dance performers can be divided into male and female, and into 'soft' and 'hard' characters. Balinese dance is known for agility, dynamics, expressions and drama using a combination of four types of movements, namely: agem, tandang, tangkis and tangkep (Dibia 2013: 64). Firstly, agem is a basic form of dance motion that is done in place, or without displacing of the axis of the body or moving from the point of departure. These motions are generally made through changes in the position of the body and limbs, including bending and straightening the knees, rotating the foot, positioning the hand without moving the axis of the body from its original position. In agem, there is the distinction between male and female characters, and soft and hard characters.

The second type of movement, tandang, is a moving posture. There are few types of tandang in Balinese dance, namely: gandang-gandang, malpal and nayog. Gandanggandang is a dignified slow movement whereby both hands are extended and held up to shoulder level. Between steps, one of the elbows turns in slightly bent. Malpal is a rapid movement with one hand held at an angle to the body and the other bent forward of the body. Nayog is a dignified slow movement whereby each step is initiated by a subtle rotation of the free foot taking the step, followed by a gentle swaying of the body as it moves forward (Dibia 2000: 23).

Thirdly, tangkis are elaborative movements that enrich phases or sequences in the existing movement. Various movements classified into tangkis include ulap-ulap, nabdab gelung, nabdab karna, and nepak dada. Most tangkis movements appear as parts of agem and tandang in addition to being executed independently (Dibia 2013: $65)$.

Fourth, tangkep refers to facial expressions and eye movements. Tangkep are performed to communicate various expressions, such as sadness, excitement, romance 
and tension. A sub-category of tangkep is the seledet or eye movements. Some types of Balinese dance, such as Gambuh, Arja and Wayang Wong include monologues and dialogues in Balinese or old Javanese languages. Monologues and dialogues are also performed using soft and hard characters.

\section{Balinese Traditional Music}

Balinese traditional music is often referred to as "karawitan", a term which is used in other parts of Indonesia (Java, Bali, Lombok, Sumatra, and Sulawesi), wherein the pentatonic tune system called pelog and selendro is practised the most. The art of traditional Balinese music can be distinguished into two categories: vocal and instrumental. In vocal music, the human voice is the main source of sound. As for instrumental music, tools (instruments) are the main source of sound.

There are four types of Balinese vocal music: gegendingan, macapat, kidung and kekawin. These four types of vocal music have systems and standard rules.

Gegendingan, commonly known as sekar rare, is the simplest form of vocal music; it is not as bound by compositional rules as the other forms, uses bahasa Bali lumrah (common Balinese language) and is sung syllabically. Its simple form results in its popularity among children whilst playing games. Macapat, also known as sekar alit, is more complex in its form, and uses bahasa Bali halus (refined Balinese language); it is bound by compositional rules known as pada lingsa, which defines the number of stanzas in a song, the number of syllables in a stanza, and the drop in tone in the final stanza of each song. Macapat is often performed in Arja dance-drama or ballet, a typical traditional Balinese opera in which most of the dialogue is expressed through singing. Kidung is more complex than macapat, and uses refined Balinese and old Javanese languages. Kidung vocal music is performed for devotional songs in ritual activities. Kekawin, or sekar ageng, is the most complex form of Balinese vocal music, using Old Javanese language. The content in kekawin relates to religion as the basis for leading people to the right path.

Barungan $^{8}$, or Balinese instrumental music ensemble, is more widely known as gamelan. One complete set or barung of the gamelan is commonly made up of various instruments, such as the gong, cymbals, drum, metal-keyed instruments, flute, and rebab. The shape of the instruments employed in the gamelan is similar to those found throughout Southeast Asia, notably in Myanmar, Thailand, Cambodia and Laos, but Southeast Asian instrumental ensembles are usually comprised of smaller instruments (McPhee 1966: xiii). As of today, there are roughly 33 types of barung or sets of gamelan ensembles in Bali, ranging from the simplest one with four instruments (gender wayang) to more complex and larger ones such as Gong Gede, which uses 70 instruments and musicians. Each set of Balinese gamelan is classified by size, tune system, repertoire, function, and types of instrument.

Balinese gamelan is strongly connected to Hindu rituals. Examples include Gambang, Selonding, Gender Wayang, Gong Gede and Angklung Kelentangan. Gamelan

\footnotetext{
${ }^{8}$ Barungan is similarly understood as ensemble or a unity of various types of music instruments there are at least 35 types of barungan gamelan in Bali at the present day which each of them has different characteristics and function among Balinese society.
} 
Gambang is associated with ancient gamelan, simple in form and played by six players. When it is played during a cremation ceremony (rites of death), the function of the Gamelan Gambang is tied to the belief that the sounds of the gamelan penetrate heaven so as to entertain the gods. Entertaining the gods through Gambang is believed to help the spirit of the deceased to reach heaven. Other myths exist, such as in Sempidi Village, Badung Regency, where the inhabitants believe that the sounds made by the xylophone and a repertoire of songs called Kebo Dungkul must be played at midnight to silence the demons and evil spirits, so that they may not disturb the tranquility of those conducting the ceremony (Rai 1992: 17).

Gamelan Selonding is also the sacred music of the community of Tenganan Village, Karangasem Regency, who are considered as the original people of Bali (Fig. 10). The sacred Gamelan Selonding of Tenganan is only played during the series of Dewa Yadnya ceremonies, and its performance is considered as an important factor in contributing to the success of the ceremony. For the people of Tenganan, Gamelan Selonding, locally known as Ida Bagus Betara Selonding, embody the sounds of god, so that their beauty can give peace and tranquility to mankind. The performance of Gamelan Selonding during the ceremony is believed to enable the gods to descend from heaven and give their blessing to mankind. It is for this reason that Gamelan Selonding is highly respected, consecrated and properly maintained.

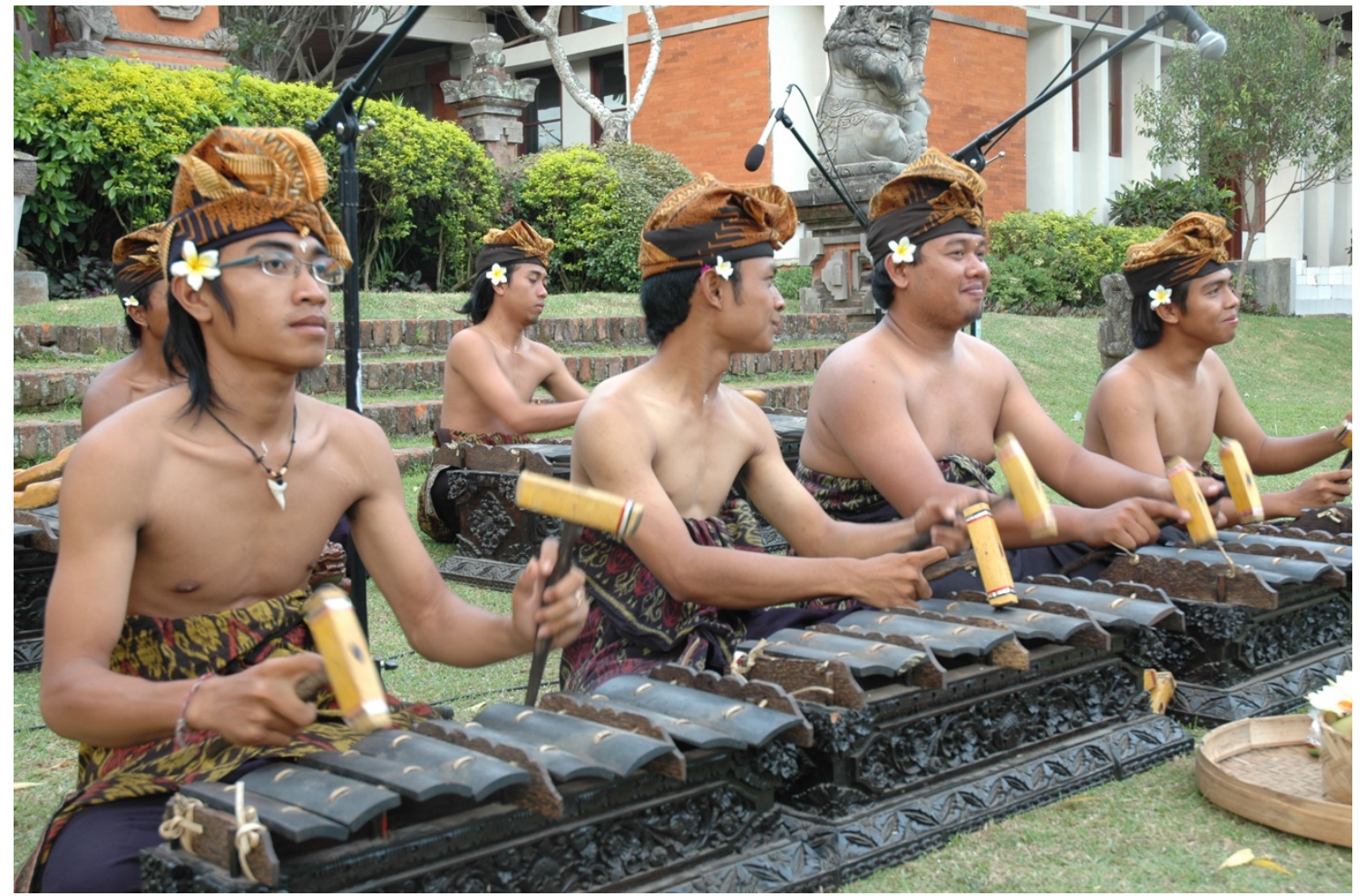

Fig. 10 Gamelan Selonding. Source: Archive Center of ISI Denpasar

As for Gamelan Gender Wayang, its primary function is to accompany shadow puppet performances, which are believed to be strongly connected to Hindu beliefs. The sounds of Gender Wayang are called "kumbang atarung", or "fighting wasps", and are believed to reduce the burden of Lord Kala when trying to prey on Rare Kumara, a child born on the day of Tumpek Wayang. The assuaging vocals of Gender 
Wayang and the puppeteer's performance are believed to dissuade Lord Kala from preying on Rare Kumara. The significance of this performance in Hindu mythology is the belief that music can reduce anger and prevent evil actions that can negatively affect mankind.

Gamelan Angklung Klentangan is also known as the "sound of death", because whenever it is heard, it is a sign of grieving. The sounds of the Angklung Klentangan's four selendro tones represent, among the Balinese, a musical expression of compassion and sorrow. As a result, Angklung Klentangan is performed in the event of death, such as the procession of carrying the body to the cemetery, the funeral home, or the cremation site. According to local mythical beliefs, the sound of the Angklung Klentangan played during a funeral ceremony helps to pave the way for the soul of the dead to reach Nirvana and become a god.

Gamelan Gong Gede, as the largest gamelan in shape and number of instruments and musicians, incorporates great, heavy and magnificent vocals (Fig. 11). These vocals are suited in strengthening the atmosphere of solemn ceremonies in the temple so as to provide a sense of peace for the people who are conducting the ceremony. In addition, Gamelan Gong Gede also serves to accompany sacred dances performed in the temple, such as Baris Gede, Rejang and Topeng Sida Karya. For a renowned temple in the regency of Bangli, named Pura Batur, the performance of the Gamelan Gong Gede is considered to be very sacred. The instruments are well cared for and are given a special place. The players are carefully selected and undergo spiritual cleansing, and carry out ritual offerings before and after the performance. The performance of the Gamelan Gong Gede Batur represents the village community's tribute to honour the gods of Batur Temple. As a result, the Gamelan Gong Gede of Batur Temple has a very magical nuance of music to support the carrying out of the temple ceremony.

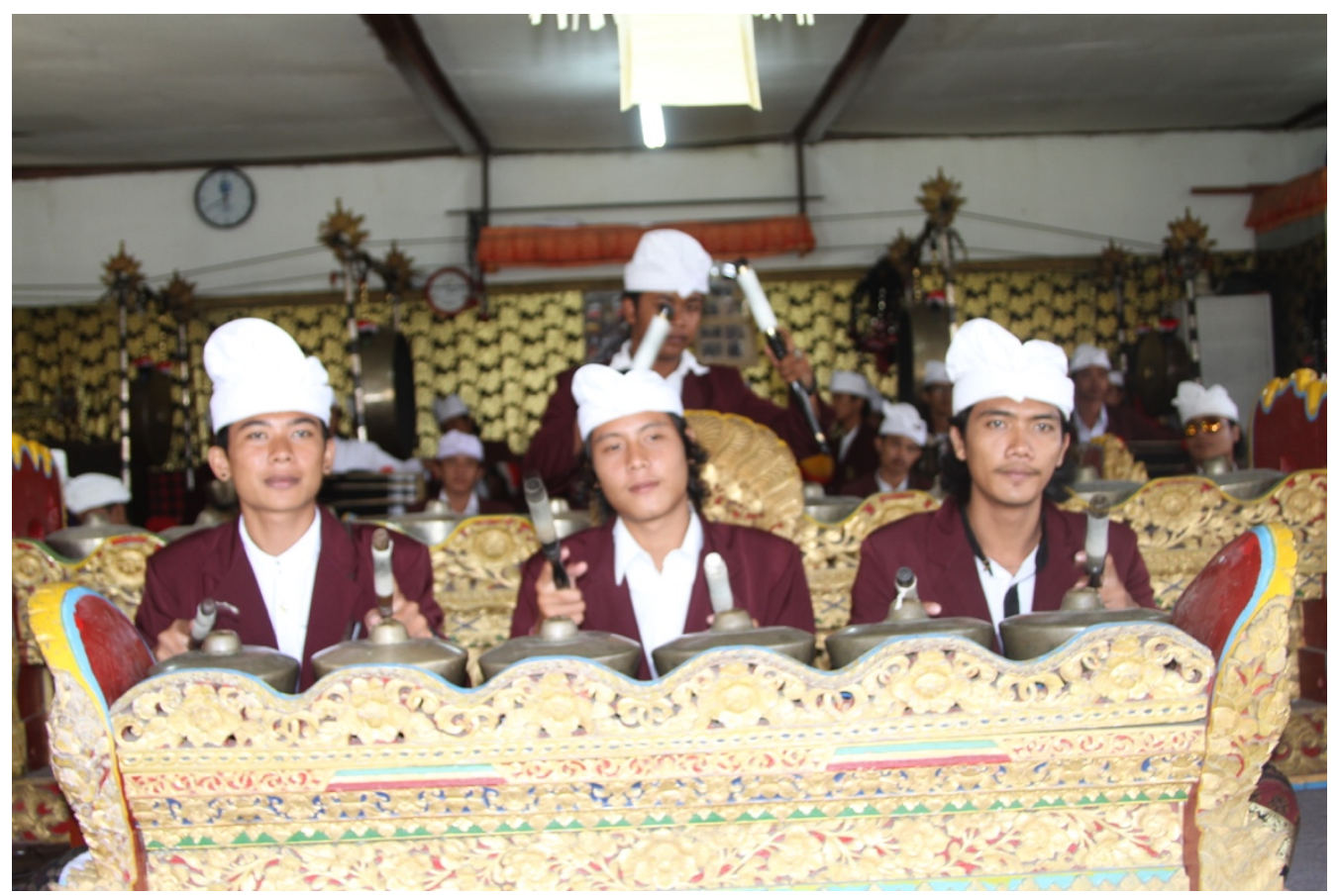

Fig. 11 Gamelan Gong Gede. Source: Archive Center of ISI Denpasar 
The Gamelan used for the SEAMEO SPAFA workshop activity during the "Hindu Arts in Southeast Asia" programme is a Gamelan Gong Gede owned by Institut Seni Indonesia Denpasar. Its instruments are the same as those of the ensemble of Batur Temple, and are classified according to the function of each: melodic instrument, colotomic instrument, and rhythmical instrument. The melodic instruments lead the melody, and include the terompong, penunggal, pengangkep ageng, pengangkep alit and reyong. Colotomic instruments refer to those that play a role in determining or emphasizing segments of the song, such as the jublag, jegogan, kempli, kempul and gong. The gong is a colotomic instrument used to finalize a sequence in the song. As for rhythmical instruments, their role is to enrich the rhythm, and include the kendang and cengceng kopyak. The kendang (drum) instrument is often called the rhythmic leader as the kendang is commonly performed to start the song, act as a beat determiner, give accentuation to the song, and indicate the song's end.

The structure of the repertoire of Balinese music is constructed into eight counts, and every last eighth count is marked by the beat of the gong, for instance: 1-2-3-4-5-6-7[gong beat]. The performance and function of every instrument in a repertoire/song can be determined in the song pattern, called $g i l a k^{9}$, which is the simplest song form in Balinese music. Starting with the rhythm played by the kajar, the eight following counts would end with the sound of the gong. The terompong instrument is played from that count to introduce the main melody, following the rhythm of the kajar: ndang, ndung, ndeng, ndong, ndang, nding, ndong, (ndeng) ${ }^{10}$. Then the kempur instrument arrives on the fifth and seventh counts. The jegogan and jublag instruments are then played to emphasize every segment of the song, prompting the pengangkep ageng with a denser blow than the main melody played by the terompong. Meanwhile, the pengangkep alit instrument is played to lock the configuration together. The reyong instrument also takes part in enriching the melody by linking the sounds together. The cengceng kopyak is performed to enrich the rhythm, preceded by the flute to soften the melody. Once all the instruments are played, the kendang takes the lead during the course of the song, organizing the dynamics and signalling the end of the song.

\section{Conclusion}

Balinese traditional dance and music are closely tied to Hinduism. Balinese Hindus in particular strongly believe that dance and music can bring them closer to almighty God. Through dance and music, Hindu peoples may express their adoration for the greatness of God to invoke blessings, salvation, welfare and good health. It is also through dance and music that Balinese Hindus can express their gratitude for having been born human, which is considered to be a noble creature. The Balinese interact with each other, with nature and with the gods, and maintain harmony in daily life through the performing arts. All forms of dance and music require collective effort in

\footnotetext{
${ }^{9}$ Gilak is a simple song within Balinese instrumental music. Aside from gilak there are some types of song such as bapang, lelonggoran, legodbawa yang, and sesimbaran.

${ }^{10}$ Terminology of ndang, ndung, ndeng, ndong, ndang, nding, ndong, (ndeng) is a sound imitation of gangsa instrument within gamelan Gong Gede, to this extend can be said as the way of reading Balinese musical notation.
} 
working together, in the belief that this will lead to peaceful coexistence. The Balinese also believe that the natural environment should be maintained for the sake of human survival. Many supernatural powers held by Mother Nature contribute to harmony in the universe through music and dance. As a result, dance and music are developed, preserved or evolve over time. The strong adherence to Hinduism among the Balinese is a factor in the continuous preservation of traditional dance and music so that these may never be lost.

\section{References}

Bagus, I G N (1985) Upacara Ruwatan Di Bali [the Ruwatan Ceremony in Bali] In: RM Soedarsono, D Soekiman and R Astuti (eds.) Celaka, Obat, dan Sehat Menurut Konsepsi Orang Jawa. Yogyakarta: Departemen Pendidikan dan Kebudayaan. Google Scholar search

Bandem, I M (1988) Prakempa Sebuah Lontar Gamelan Bali [Prakempa: an inscription of Balinese Music]. Denpasar: Sekolah Tinggi Seni Indonesia. Google Scholar search

Bandem, I M and de Boer, F E (2004) Kaja dan Kelod Tarian Bali Dalam Transisi [North and South Balinese Dance in Transition], trans. I Made Marlowe Makaradhwaja Bandem. Yogyakarta: Badan Penerbit Institut Seni Indonesia Yogyakarta. Google Scholar search

Dibia, I W (1985) Odalan of Hindu Bali: A religious festival, a social occasion, and a theatrical event. Asian Theatre Journal 2(1): 61-65. Crossref

Dibia, I W (2000) Kecak The Vocal Chant of Bali. Denpasar: Hartanto Art Books Bali. Google Scholar search

Dibia, I W (2013) Puspasari Seni Tari Bali [Significance of Balinese Dance]. Denpasar: UPT Penerbitan ISI Denpasar. Google Scholar search

McPhee, C (1966) Music in Bali: A Study in Form and Instrumental Organization in Balinese Orchestral Music. New Haven and London: Yale University Press. Google Scholar search

Rai S, I W (1992) Gamelan Gambang Di Sempidi: Deskripsi, Fungsi, dan Struktur Gendingnya [Gamelan of Gambang in Sempidi: Description, Function, and Structure of Its Song]. Paper presented in Gambang Art Seminar and Workshop, Bali, Indonesia. Google Scholar search

Soedarsono, R M (1985) Peranan Seni Budaya Dalam Sejarah Kehidupan Manusia, Kontinuitas dan Perubahannya [Role of Arts and Culture in the History of Human Life, Continuity and Change]. Professorship Speech at Faculty of Literature Gadjah Mada University, Yogyakarta. Google Scholar search

Tim, P (2005) Statuta Institut Seni Indonesia Denpasar [The Statutes of Indonesia institute of Arts Denpasar]. Jakarta: the Ministry of Education and Culture of the Republic of Indonesia. Google Scholar search 